\title{
PENGARUH INFORMASI AKUNTANSI TERHADAP KEBERHASILAN USAHA KECIL DAN MENENGAH STUDI PADA UKM PENGRAJIN KULIT DI BANTUL
}

\author{
Surya Kresna Anggara \\ Rohmad Yuliantoro Catur Wibowo
}

Accounting information useful for measuring and communicating information a finance company that desperately needs the management in the formulation of various decisions made to solve the problems faced by. This study attempts to get a clear on the influence of accounting information to successful smes craftsman the skin on bantul. The research is research quantitative with method the sample used is purposive sampling. The kind of data that used was the data primary. Data processing done using the tools spss 19 to technique regression analysis linear multiple. This research result indicates that information accounting simultaneously influential to successful smes. Variable financial report in partial do not affect. While planning effective, decision-making, the determination of hpp, and the determination of the selling price influential to successful smes. The result of this research also suggested that variable an independent in this study can influence the success of smes of $52 \%$, the rest influenced by a factor of other than this research.

Password: financial report, planning effective, decision-making, the determination of hpp, and the determination of the selling price.

\section{PENDAHULUAN}

Indonesia dihadapkan dengan sebuah persaingan di bidang perekonomian di tingkat internasional. Tepatnya di tahun 2015 Indonesia bersaing dengan negaranegara di kawasan Asia Tenggara yang tergabung dalam ASEAN Economic Community (AEC). AEC 2015 akan diarahkan kepada pembentukan sebuah integrasi ekonomi kawasan dengan mengurangi biaya transaksi perdagangan, memperbaiki fasilitas perdagangan dan bisnis, serta meningkatkan daya saing sektor Usaha Kecil Menengah (UKM) (http://www.setneg.go.id/).

Banyak usaha yang berkembang di Indonesia terutama usaha-usaha kecil dalam hal ini adalah unit Usaha Kecil dan Menengah (UKM). Produk-produk yang dihasilkan pun bervariasi. Jika dicermati banyak produk yang apabila dikembangkan dapat memiliki nilai tinggi dan dapat bersaing dengan produk-produk asing. Namun disayangkan, pelaku UKM di Indonesia belum memperhatikan pentingnya pengetahuan akuntansi dan tidak menggunakan informasi akuntansi dalam menjalankan bisnisnya. Berdasarkan data banyaknya desa/kelurahan menurut 
keberadaan dan jenis industri kecil dan mikro 2014 khususnya Yogyakarta pada sektor industri dari kulit berjumlah 116. UKM yang cukup berkembang sangat pesat adalah UKM kerajinan dengan bahan kulit yang terdapat di Bantul Yogyakarta. Kawasan yang cukup terkenal akan hasil kerajinan berbahan dasar kulit tersebut adalah di kawasan Manding dan Pucung.

Banyaknya desa/kelurahan menurut keberadaan dan jenis industri kecil dan mikro 2014 pada sektor industri dari kulit di Yogyakarta dapat ditingkatkan kembali. Perlu adanya perbaikan pengelolaan agar dari data yang berjumlah 116 dapat meningkat. Salah satunya adalah dengan pemahaman akan pentingnya informasi akuntansi pada para pelaku usaha/UKM. Pinasti (2007) menyatakan, penggunaan informasi akuntansi didorong oleh adanya persepsi yang baik dari pihak manajemen perusahaan. Oleh karena itu, untuk dapat mendorong pengusaha kecil menggunakan informasi akuntansi perlu dimulai dari persepsi pengusaha kecil tersebut terhadap informasi akuntansi.

Laporan keuangan merupakan suatu alat gambar kondisi usaha (kemajuan atau kemunduran), pengambil keputusan yang akurat dan tepat waktu serta pertanggungjawaban pada manajemen serta yang terpenting secara mendasar adalah pemahaman makna laba atau rugi yang diperoleh dari hasil usahanya. Oleh karena itu, laporan keuangan sangat berguna untuk menilai kinerja usaha dan dapat membantu dalam menghadapi permasalahan dalam menjalankan usaha khususnya UKM (Harahap, 2014).

Nicholls dan Holmes (1988) dalam Wahyudi (2009) mengemukakan bahwa informasi akuntansi sangat bermanfaat bagi UKM, karena merupakan alat yang digunakan oleh pengguna informasi untuk pengambilan keputusan. Informasi akuntansi dapat digunakan untuk mengukur dan mengkomunikasikan informasi keuangan perusahaan yang sangat diperlukan oleh pihak manajemen dalam merumuskan berbagai keputusan untuk memecahkan permasalahan yang dihadapi. Pengambilan keputusan menjadi salah satu faktor yang penting untuk keberhasilan suatu usaha.

Harga pokok produksi dalam industri merupakan bagian terbesar dari biaya yang harus dikeluarkan perusahaan. Jika informasi biaya untuk pekerjaan atau proses tersedia dengan cepat, maka manajemen mempunyai dasar yang kuat untuk 
merencanakan kegiatannya (Rachmayanti, 2011). Pelaku usaha juga tidak luput dari penentuan harga jual. Penentuan harga jual adalah salah satu faktor penting dalam keberlangsungan dan keberhasilan suatu usaha. Megginson et al. (2000) dikutip dalam Pinasti (2007), menyatakan bahwa informasi akuntansi mempunyai peran penting untuk mencapai keberhasilan usaha, termasuk bagi usaha kecil. Pelaku UKM memiliki kewajiban untuk menyelenggarakan pencatatan akuntansi yang baik. Hal ini terdapat dalam Undang-Undang Usaha Kecil dan Menengah Nomor 9 Tahun 1995 (Pinasti, 2007).

Penelitian mengenai pengaruh informasi akuntansi dan motivasi karyawan terhadap keberhasilan UKM telah dilakukan oleh Permana (2014) dengan studi di UKM knalpot di Purbalingga. Hasil penelitian dapat disimpulkan bahwa laporan keuangan, perencanaan yang efektif, pengambilan keputusan dinyatakan tidak berpengaruh terhadap keberhasilan UKM, sedangkan penentuan harga jual dan motivasi karyawan berpengaruh terhadap keberhasilan UKM. Prasetya (2006) dalam Permana (2014) menyatakan bahwa pengaruh informasi akuntansi terhadap keberhasilan UKM bersifat positif. Penelitian tentang analisis perhitungan harga pokok produksi sepatu dengan metoda full costing dilakukan oleh Rachmayanti (2011) menunjukkan bahwa UKM Galaksi menerapkan perhitungan harga pokok produksi masih sangat sederhana. Elemen biaya yang dihitung dengan menggunakan metoda perusahaan meliputi biaya bahan baku langsung, biaya tenaga kerja langsung dan biaya overhead pabrik (biaya lain-lain).

Penelitian ini terinspirasi dari penelitian Permana (2014). Perbedaan penelitian ini dengan penelitian sebelumnya adalah penambahan satu variabel independen yaitu penentuan harga pokok produk yang diambil dari penelitian Rachmayanti (2011) dan Widiyastuti (2007). Penentuan harga pokok produksi yang benar sangat penting bagi perusahaan dalam menjalankan usahanya (Widiyastuti, 2007). Berdasarkan latar belakang, maka peneliti tertarik untuk meneliti mengenai pengaruh informasi akuntansi terhadap keberhasilan usaha kecil dan menengah studi pada UKM pengrajin kulit di Bantul. 


\section{TINJAUAN PUSTAKA DAN PENGEMBANGAN HIPOTESIS}

\section{Informasi Akuntansi}

Prasetya (2006) dikutip dalam Permana (2014) menyatakan bahwa informasi adalah data-data yang telah diproses dengan cara-cara tertentu sehingga berguna untuk pengambilan keputusan. Informasi yang digunakan dalam perusahaan dibagi menjadi informasi kuantitatif dan informasi non kuantitatif. Faktor-faktor informasi akuntansi yang mempengaruhi keberhasilan UKM Kerajinan Kulit di Bantul yaitu sebagai berikut:

1. Laporan Keuangan

Menurut PSAK Nomor 1 (IAI, 2009) laporan keuangan adalah suatu penyajian terstruktur dari posisi keuangan dan kinerja keuangan suatu entitas. Tujuan laporan keuangan adalah memberikan informasi mengenai posisi keuangan, kinerja keuangan, dan arus kas entitas yang bermanfaat bagi sebagian besar kalangan pengguna laporan dalam pembuatan keputusan ekonomi.

2. Perencanaan yang efektif

Perencanaan merupakan salah satu fungsi utama dari manajemen. Secara umum perencanaan merupakan proses penentuan tujuan organisasi (perusahaan) dan menyajikan dengan jelas strategi-strategi (program), taktik-taktik (tata cara pelaksanaan program) dan operasi (tindakan) yang diperlukan untuk mencapai tujuan perusahaan secara menyeluruh (Suandy, 2001: 1).

3. Pengambilan Keputusan

Pengambilan keputusan adalah proses pemilihan alternatif terbaik di antara berbagai alternatif yang ada. Pengambilan keputusan hanya dapat terlaksana apabila tersedia informasi. Kualitas informasi yang tersedia akan menentukan kualitas keputusan yang diambil manajemen (Wirjoyo dan Raharjo, 2012).

4. Harga Pokok Produksi

Harga pokok produksi atau disebut harga pokok adalah pengorbanan sumber ekonomi yang diukur dalam satuan uang yang telah terjadi atau kemungkinan terjadi untuk memperoleh penghasilan (Mulyadi, 2007: 10).

5. Penentuan Harga Jual

Prasetya (2006) dikutip dalam Permana (2014) Informasi akuntansi berperan dalam penentuan harga jual produk, manajemen harus memperhatikan 
dan mempertimbangkan faktor-faktor yang pempengaruhi harga jual yang disesuaikan dengan jenis UKM, produk dan pasarnya.

\section{Keberhasilan UKM}

UKM memiliki beberapa keragaman definisi (Rahmana, 2008) diantaranya adalah sebagai berikut:

1. Usaha Kecil (UK) adalah entitas usaha yang memiliki kekayaan bersih paling banyak Rp200.000.000, tidak termasuk tanah dan bangunan tempat usaha, dan memiliki penjualan tahunan paling banyak Rp1.000.000.000. Sementara itu, Usaha Menengah (UM) merupakan entitas usaha milik warga negara Indonesia yang memiliki kekayaan bersih lebih besar dari Rp200.000.000 sampai dengan Rp10.000.000.000, tidak termasuk tanah dan bangunan.

2. Badan Pusat Statistik (BPS) memberikan definisi UKM berdasarkan kuantitas tenaga kerja. Usaha kecil merupakan entitas usaha yang memiliki jumlah tenaga kerja 5 sampai dengan 19 orang, sedangkan usaha menengah merupakan entitias usaha yang memiliki tenaga kerja 20 sampai 99 orang.

3. Penetapan Undang-Undang Nomor 20 Tahun 2008 tentang Usaha Mikro, Kecil, dan Menengah pada 4 Juli 2008 telah ditetapkan. Definisi UKM yang disampaikan oleh Undang-Undang ini juga berbeda dengan definisi di atas.

Keberhasilan perusahaan kecil ditinjau dari dua sudut pandang yaitu sudut pandang ekonomi dan sudut pandang sosial. Segi ekonomi, keberhasilan perusahaan dapat ditinjau dari adanya peningkatan kekayaan perusahaan di luar pinjaman, misalnya kenaikan laba, tambahan modal sendiri, dan rasio-rasio yang lain. Sedangkan dari segi sosial, keberhasilan perusahaan ditinjau dari adanya kelangsungan hidup perusahaan yang terkait dengan keberhasilan karyawan perusahaan dan pelayanan kepada pelanggan (Hanum, 2013).

Menurut Heckert (1995:84) dalam Hanum (2013), untuk mengukur keberhasilan perusahaan dapat digunakan tolok ukur profitabilitas dan tolok ukur pertumbuhan ekonomi. Keberhasilan usaha menurut Haryadi (1998:78) dalam Wibowo (2013), diartikan dengan membesarnya skala usaha yang dimilikinya hal tersebut bisa dilihat dari volume produksi yang tadinya bisa menghabiskan sejumlah bahan baku perhari meningkat menjadi mampu mengolah bahan baku yang lebih 
banyak. Menurut Haryadi (1998) dalam Wibowo (2013), kriteria keberhasilan usaha dilihat dari peningkatan omzet penjualan dapat dibagi sebagai berikut:

a. Tingkat banyaknya order

b. Tingkat promosi pesanan

c. Tingkat harga yang ditawarkan

d. Tingkat penghasilan dari penjualan

\section{Laporan Keuangan terhadap Keberhasilan Usaha Kecil Menengah}

Laporan Keuangan merupakan suatu alat gambar kondisi usaha (terjadi kemajuan atau kemunduran), pengambil keputusan yang akurat dan tepat waktu serta pertanggungjawaban pada manajemen serta yang terpenting secara mendasar adalah pemahaman makna laba atau rugi yang diperoleh dari hasil usahanya. Oleh karena itu, laporan keuangan sangat berguna untuk menilai kinerja usaha dan dapat membantu dalam menghadapi permasalahan dalam menjalankan usaha khususnya UKM (Harahap, 2014).

Tujuan laporan keuangan adalah memberikan informasi mengenai posisi keuangan, kinerja keuangan, dan arus kas entitas yang bermanfaat bagi sebagian besar kalangan pengguna laporan dalam pembuatan keputusan ekonomi. Kiryanto dan Sutapa (2001) dalam Prasetya (2006) dikutip dalam Permana (2014), berdasarkan penelitiannya bahwa persepsi manajer perusahaan kecil atas informasi akuntansi keuangan berpengaruh terhadap keberhasilan perusahaan kecil. Berdasarkan uraian tersebut, maka dapat dirumuskan hipotesis sebagai berikut:

$\mathrm{H}_{1}$ : Laporan keuangan berpengaruh terhadap keberhasilan UKM kerajinan kulit di Bantul.

\section{Perencanaan yang Efektif terhadap Keberhasilan Usaha Kecil Menengah}

Menurut Suandy (2001), kegunaan dari pembuatan perencanaan adalah terciptanya efisiensi dan efektivitas pelaksanaan kegiatan perusahaan, dapat melakukan koreksi atas penyimpangan sedini mungkin, mengidentifikasi hambatanhambatan yang timbul, menghindari pertumbuhan dan perubahan yang tidak terarah dan terkontrol. Permana (2014) mengemukakan perencanaan yang efektif merupakan proses penentuan tujuan perusahaan dan kemudian menyajikan dengan jelas strategi- 
strategi, tata cara pelaksanaan program dan operasi yang diperlukan untuk mencapai tujuan perusahaan secara menyeluruh.

Suhairi (2006) dalam Mujib (2010) menyimpulkan bahwa strategi bisnis juga mempunyai pengaruh positif terhadap prestasi perusahaan. Darmawan (2004) dalam Mujib (2010) mengemukakan bahwa strategi dibutuhkan oleh suatu organisasi yang menitikberatkan pada profit oriented dan non-profit oriented seperti rumah sakit, universitas, masjid, pemerintah daerah, perpustakaan, dan lembaga sosial lainnya. Beberapa hasil penelitian menunjukan bahwa organisasi yang mempunyai strategi yang jelas atau formal, lebih unggul (outperformed) kinerjanya dibanding dengan organisasi tanpa atau tidak terformulasikan dengan jelas strateginya. Berdasarkan uraian tersebut, maka dapat dirumuskan hipotesis sebagai berikut:

$\mathrm{H}_{2}$ : Perencanaan yang efektif berpengaruh terhadap keberhasilan UKM kerajinan kulit di Bantul.

\section{Pengambilan Keputusan terhadap Keberhasilan Usaha Kecil Menengah}

Pengambilan keputusan adalah suatu proses pemilihan alternatif terbaik di antara berbagai alternatif yang ada. Pengambilan keputusan hanya dapat terlaksana apabila tersedia informasi. Kualitas informasi yang tersedia akan menentukan kualitas keputusan yang diambil manajemen (Wirjoyo dan Raharjo, 2012). Brahmasari dan Suprayetno (2008) dalam Permana (2014) mengemukakan dalam penelitiannya bahwa pengambilan keputusan berpengaruh terhadap kinerja perusahaan dan keberhasilan perusahaan. Berdasarkan uraian tersebut, maka dapat dirumuskan hipotesis sebagai berikut:

H3: Pengambilan keputusan berpengaruh terhadap keberhasilan UKM kerajinan kulit di Bantul.

\section{Penentuan Harga Pokok Produksi terhadap Keberhasilan Usaha Kecil Menengah}

Menurut Mulyadi (2007: 10), harga pokok produksi atau disebut harga pokok adalah pengorbanan sumber ekonomi yang diukur dalam satuan uang yang telah terjadi atau kemungkinan terjadi untuk memperoleh penghasilan. Rachmayanti (2011) dalam penelitiannya menyimpulkan bahwa, perhitungan harga pokok 
produksi dengan metoda full costing diperoleh biaya produksi yang lebih tinggi dari pada metoda perhitungan dengan metoda perusahaan. Perhitungan harga pokok produksi menjadi salah satu hal penting untuk dilakukan bagi setiap perusahaan.

Widiyastuti (2007) dalam penelitiannya menyatakan bahwa, perhitungan harga pokok produksi yang dilakukan perusahaan masih sangat sederhana dan dengan menggunakan metoda sendiri. Harga pokok produksi sangat berpengaruh dalam perhitungan laba rugi perusahaan, apabila perusahaan kurang teliti atau salah dalam penentuan harga pokok produksi, mengakibatkan kesalahan dalam penentuan laba rugi yang diperoleh perusahaan (Rozi, 2010). Hal tersebut juga berpengaruh terhadap keberlangsungan dan keberhasilan usaha. Berdasarkan uraian teoritis, maka dirumuskan hipotesis sebagai berikut:

H4: Penentuan harga pokok produksi berpengaruh terhadap keberhasilan UKM kerajinan kulit di Bantul.

\section{Penentuan Harga Jual terhadap Keberhasilan Usaha Kecil Menengah}

Harga jual merupakan salah satu elemen penting yang mendukung keberhasilan suatu perusahaan, apalagi jika pasar untuk industri tersebut price sensitive. Kesalahan dalam penetapan harga jual dapat mengakibatkan perusahaan kehilangan pelanggan sehingga perusahaan tidak dapat bertahan dalam usahanya (Martusa dan Agnes, 2011). Penelitian yang dilakukan oleh Lembang (2010) dalam Permana (2014), menunjukkan adanya pengaruh antara harga jual produk terhadap keberhasilan perusahaan. Penelitian mengenai pengaruh informasi akuntansi dan motivasi karyawan telah dilakukan oleh Permana (2014) menyimpulkan bahwa harga jual berpengaruh terhadap keberhasilan UKM. Berdasarkan uraian teoritis, maka dirumuskan hipotesis sebagai berikut:

H5: Penentuan harga jual berpengaruh terhadap keberhasilan UKM kerajinan kulit di Bantul.

\section{Model Penelitian}

Model rerangka penelitian dalam penelitian ini dibuat untuk mempermudah pemahaman mengenai pengaruh informasi akuntansi terhadap keberhasilan usaha 
kecil dan menengah. Sesuai dengan penelitian ini, maka rerangka penelitian adalah sebagai berikut:

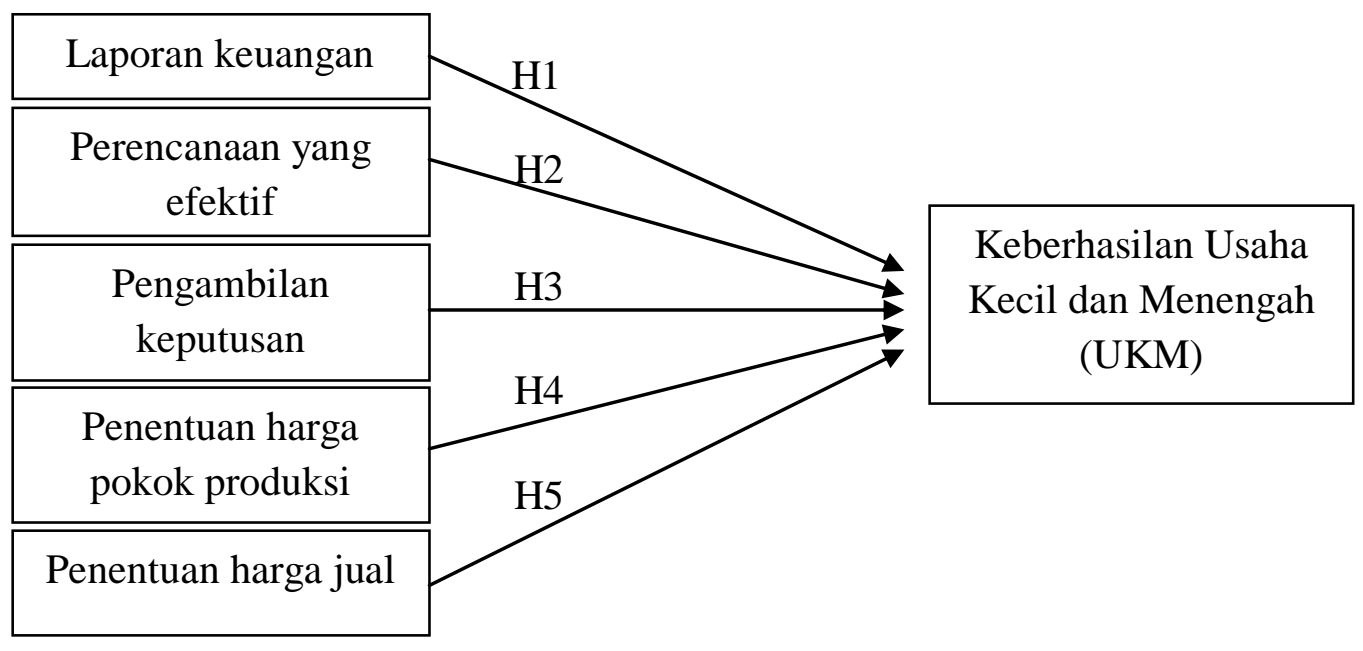

Gambar 1

Rerangka Penelitian

\section{METODA PENELITIAN}

\section{Populasi, Sampel, dan Teknik Pengambilan Sampel}

Populasi dalam penelitian ini adalah UKM pengrajin kulit yang ada di Bantul. Sampel dalam penelitian ini adalah UKM pengrajin kulit di Manding dan Pucung. Sampel dipilih berdasarkan metoda purposive sampling, yaitu pemilihan sampel dengan kriteria tertentu. Penggunaan kriteria dalam penelitian ini adalah:

a. UKM pengrajin kulit di Bantul yang termasuk dalam kategori usaha kecil dengan penjualan tahunan total kurang dari Rp500.000.000 dan menerapkan teknologi sederhana.

b. Lama UKM didirikan 5 sampai 10 tahun, dengan maksud dalam kurun waktu tersebut keadaan UKM sudah stabil dan masih bertahan.

\section{Jenis dan Sumber Data}

Data yang digunakan dalam penelitian ini adalah data primer. Sumber data yang diperoleh secara langsung dari responden melalui kuesioner dan melakukan wawancara.

Pengumpulan data dalam penelitian ini yaitu dengan survei dan penyebaran kuesioner kepada subjek penelitian dengan kriteria tertentu. Skala pengukuran yang 
digunakan dalam penelitian ini adalah skala Likert 5 poin. Skala Likert didesain untuk menelaah seberapa kuat subjek dalam menjawab pertanyaan dengan 5 poin penilaian (Sekaran, 2006: 31-32):

Tabel 1

Skala Pengukuran Pertanyaan

\begin{tabular}{|c|c|c|c|c|c|}
\hline Keterangan & SS & S & N & TS & STS \\
\hline Pertanyaan Positif & 5 & 4 & 3 & 2 & 1 \\
\hline Pertanyaan Negatif & 1 & 2 & 3 & 4 & 5 \\
\hline
\end{tabular}

Sumber: Sekaran (2006) dalam Permana (2014)

Keterangan:

$$
\begin{array}{ll}
\mathrm{SS} & =\text { Sangat Setuju } \\
\mathrm{S} & =\text { Setuju } \\
\mathrm{N} & =\text { Netral } \\
\mathrm{TS} & =\text { Tidak Setuju } \\
\text { STS } & =\text { Sangat Tidak Setuju }
\end{array}
$$

\section{Definisi Operasional Variabel}

\section{Laporan Keuangan $\left(\mathbf{X}_{1}\right)$}

PSAK Nomor 1 (IAI, 2009) mendefinisikan laporan keuangan adalah suatu penyajian terstruktur dari posisi keuangan dan kinerja keuangan suatu entitas. Tujuan laporan keuangan adalah memberikan informasi mengenai posisi keuangan, kinerja keuangan, dan arus kas entitas yang bermanfaat bagi sebagian besar kalangan pengguna laporan dalam pembuatan keputusan ekonomi. Indikator laporan keuangan dalam Permana (2014) adalah:

1) Membuat laporan keuangan perusahaan.

2) Membuat laporan keuangan perusahaan menguntungkan bagi perusahaan.

3) Laporan keuangan dapat mendorong keberhasilan perusahaan.

4) Laporan keuangan dapat dijadikan dasar evaluasi kinerja perusahaan.

a. Perencanaan yang efektif $\left(\mathrm{X}_{2}\right)$

Perencanaan adalah formulasi kegiatan yang akan dilaksanakan untuk mencapai suatu tujuan tertentu yang telah ditetapkan. Perencanaan diperlukan adanya penetapan tujuan serta metoda yang akan digunakan dalam mencapai tujuan tersebut 
(Wirjoyo dan Raharjo, 2012). Indikator perencanaan yang efektif dalam Permana (2014) adalah:

1) Menentukan tujuan usaha.

2) Membuat perencanaan dalam menentukan tujuan bisnis.

3) Perencanaan yang efektif dapat meningkatkan kinerja perusahaan.

4) Perencanaan yang efektif dapat menunjang keberhasilan perusahaan.

b. Pengambilan keputusan $\left(\mathrm{X}_{3}\right)$

Pengambilan keputusan adalah suatu proses pemilihan alternatif terbaik di antara berbagai alternatif yang ada. Pengambilan keputusan hanya dapat terlaksana apabila tersedia informasi. Kualitas informasi yang tersedia akan menentukan kualitas keputusan yang diambil manajemen (Wirjoyo dan Raharjo, 2012). Indikator pengambilan keputusan dalam Permana (2014) adalah:

1) Mengambil keputusan dalam mencapai tujuan bisnis.

2) Pengambilan keputusan selalu diterima oleh karyawan.

3) Menerapkan program-program tertentu dalam tujuan bisnis.

c. Penentuan harga pokok produksi $\left(\mathrm{X}_{4}\right)$

Menurut Mulyadi (2007:10), harga pokok produksi atau disebut harga pokok adalah pengorbanan sumber ekonomi yang diukur dalam satuan uang yang telah terjadi atau kemungkinan terjadi untuk memperoleh penghasilan. Harga pokok produksi sangatlah berpengaruh dalam penentuan laba. Indikator penentuan harga pokok produksi adalah:

1) Menetapkan biaya anggaran produksi.

2) Menerapkan metoda dalam penentuan harga pokok produksi.

3) Penentuan harga pokok produksi berpengaruh terhadap alokasi biaya produksi.

d. Penentuan harga jual $\left(\mathrm{X}_{5}\right)$

Harga jual merupakan salah satu elemen penting yang mendukung keberhasilan suatu perusahaan, apalagi jika pasar untuk industri tersebut price sensitive. Kesalahan dalam penetapan harga jual dapat mengakibatkan perusahaan kehilangan pelanggan sehingga perusahaan tidak dapat bertahan dalam usahanya (Martusa dan Agnes, 2011). Indikator penentuan harga jual dalam Permana (2014) adalah: 
1) Penentuan harga jual sesuai dengan pasar.

2) Penentuan harga jual selalu memberikan laba.

3) Penentuan harga jual berpengaruh terhadap tingkat penjualan produk.

4) Penentuan harga jual sesuai dengan kualitas barang yang dipasarkan.

\section{Keberhasilan UKM}

Menurut Heckert (1995:84) dalam Hanum (2013), untuk mengukur keberhasilan perusahaan dapat digunakan tolok ukur profitabilitas dan tolok ukur pertumbuhan ekonomi. Menurut Haryadi (1998) dalam Wibowo (2013), kriteria keberhasilan usaha dilihat dari peningkatan omset penjualan dapat dibagi sebagai berikut:

a. Tingkat banyaknya order

b. Tingkat promosi pesanan

c. Tingkat harga yang ditawarkan

d. Tingkat penghasilan dari penjualan

Indikator keberhasilan UKM dalam Permana (2014) adalah sebagai berikut:

1) Laba perusahaan selalu naik dari tahun ke tahun.

2) Konsumen yang memesan produk selalu bertambah dan loyal.

3) Pemasaran produk perusahaan semakin meluas.

4) Perusahaan selalu berinovasi terhadap produk.

5) Memanfaatkan sumberdaya yang bernilai ekonomi dengan baik.

\section{TEKNIK ANALISIS DATA}

\section{Kualitas Data}

Uji validitas digunakan untuk mengukur sah atau valid tidaknya suatu kuesioner. Suatu kuesioner dikatakan valid jika pertanyaan kuesioner mampu untuk mengungkapkan sesuatu yang akan diukur oleh kuesioner tersebut (Ghozali, 2011: 52 ). Uji validitas dapat dilakukan dengan cara melihat nilai $r$ hitung dibandingkan dengan nilai $\mathrm{r}$ tabel $(\mathrm{df}=\mathrm{n}-2$ dan $\alpha=5 \%)$. Jika $\mathrm{r}$ hitung lebih besar dari $\mathrm{r}$ tabel, maka item pertanyaan tersebut dinyatakan valid (Sugiyono, 2009: 181).

Reliabilitas adalah untuk mengukur suatu kuesioner yang merupakan indikator dari variabel atau konstruk. Suatu kuesioner dikatakan reliabel atau handal 
jika jawaban seseorang terhadap pernyataan adalah konsisten atau stabil dari waktu ke waktu. Menurut Hastono (2006: 61-62) untuk mengetahui reliabilitas caranya adalah dengan membandingkan nilai $r$ hasil dengan $r$ tabel. Uji reliabilitas sebagai nilai $r$ hasil adalah nilai "alpha" (terletak di akhir output). Ketentuannya adalah bila $r$ alpha $>\mathrm{r}$ tabel, maka pertanyaan tersebut reliabel.

\section{Analisis Regresi Berganda}

$$
Y=\alpha+\beta_{1} X_{1}+\beta_{2} X_{2}+\beta_{3} X_{3}+\beta_{4} X_{4}+\beta 5 X 5+e
$$

Keterangan:

$$
\begin{array}{ll}
\mathrm{Y} & =\text { Keberhasilan UKM } \\
\alpha & =\text { Bilangan konstanta } \\
\mathrm{X} 1 & =\text { Laporan keuangan } \\
\mathrm{X} 2 & =\text { Perencanaan yang efektif } \\
\mathrm{X} 3 & =\text { Pengambilan keputusan } \\
\mathrm{X} 4 & =\text { Penentuan harga jual } \\
\mathrm{X} 5 & =\text { Penentuan Harga Pokok Produk } \\
\mathrm{e} & =\text { Error }
\end{array}
$$

\section{Uji Asumsi Klasik}

a. Normalitas

Uji normalitas bertujuan untuk menguji ada tidaknya variabel penganggu atau residual yang memiliki distribusi normal dalam model regresi (Ghozali, 2011: 160). Normalitas data dapat dilihat dari uji statistik non-parametrik onesample Kolmogrov Smirnov (K-S) dengan tingkat signifikansi 0,05.

b. Multikolinearitas

Multikolinearitas bertujuan untuk menguji model regresi ditemukan adanya korelasi antar variabel bebas (independen). Uji multikolinearitas dibuktikan dengan nilai variance inflation factor (VIF) dan nilai tolerance. Jika nilai VIF $<10$ dan tolerance $>0,10$, maka dapat disimpulkan bahwa tidak ada multikolinearitas (Ghozali, 2011: 105-106).

c. Uji Heteroskedastisitas

Uji heteroskedastisitas bertujuan untuk menguji model regresi terjadi ketidaksamaan variance dari residual satu pengamatan ke pengamatan lain. 
Pengambilan keputusan dapat dilakukan dengan melihat pada hasil pengujian $\mathrm{F}$ nilai signifikansi $<0,05$ maka menunjukkan terjadinya heteroskedastisitas, sedangkan jika nilai signifikansi > 0,05 maka tidak terjadi heteroskedastisitas.

\section{Pengujian hipotesis}

\section{a. Uji Determinasi}

Uji determinasi dapat dilakukan dengan melihat nilai adjusted $\mathrm{R}^{2}$. Nilai adjusted $\mathrm{R}^{2}$ dapat bernilai negatif, walaupun yang dikehendaki harus bernilai positif. Menurut Gujarati (2003) dalam Ghozali (2011: 97-98), jika dalam uji empiris didapat nilai adjusted $\mathrm{R}^{2}$ negatif, maka nilai adjusted $\mathrm{R}^{2}$ dianggap nilai nol. Secara sistematis jika nilai $\mathrm{R}^{2}=1$, maka adjusted $\mathrm{R}^{2}=\mathrm{R}^{2}=1$ sedangkan jika nilai $\mathrm{R}^{2}=0$, maka adjusted $\mathrm{R}^{2}=(1-\mathrm{k}) /(\mathrm{n}-\mathrm{k})$. jika $\mathrm{k}>1$, maka adjusted $\mathrm{R}^{2}$ akan bernilai negatif.

b. Uji F

Uji statistika F pada dasarnya menguji variabel independen atau bebas yang dimasukkan dalam model mempunyai pengaruh terhadap variabel dependen atau terikat (Ghozali, 2011: 98). Rumusan hipotesis yang diuji:

1. Ho: $\beta 1=\beta 2=\beta 3=\beta 4=\beta 5=0$, berarti semua koefisien sama dengan 0 atau semua variabel tidak berpengaruh.

2. Ha: $\beta 1 \neq 0$ atau $\beta 2 \neq 0$ atau $\beta 3 \neq 0$ atau $\beta 4 \neq 0$ atau $\beta 5 \neq 0$, berarti tidak semua koefisien sama dengan 0 atau ada variabel yang berpengaruh.

Menurut Kuncoro (2011:108) cara melakukan uji F dengan membandingkan nilai $\mathrm{F}$ hasil perhitungan dengan nilai F menurut tabel, bila nilai F hasil perhitungan lebih besar daripada nilai $\mathrm{F}$ menurut tabel maka kita menerima hipotesis alternatif yang menyatakan bahwa semua variabel independen secara serentak dan signifikan mempengaruhi variabel dependen.

c. Uji t

Uji t merupakan pengujian masing-masing variabel independen yang dilakukan untuk melihat masing-masing variabel independen berpengaruh terhadap variabel dependen. Dasar pengambilan keputusannya jika nilai probability $<0,05$ atau 5\%, maka variabel independen berpengaruh terhadap variabel dependen dan sebaliknya, jika nilai probability $>0,05$ atau $5 \%$ maka 
variabel independen tidak berpengaruh terhadap variabel dependen (Ghozali, 2011: 98-99).

\section{HASIL DAN PEMBAHASAN}

\section{Analisis Statistik Deskriptif}

Statistik deskriptif memberikan gambaran atau deskripsi suatu data yang dilihat dari rata-rata/mean, standar deviasi, varian, maksimum, minimum, sum, range, kurtosis, dan skewness/kemencengan distribusi (Ghozali, 2011: 19). Hasil analisis data statistik deskriptif ditampilkan dalam tabel berikut.

Tabel 2

Hasil Analisis Deskriptif

\begin{tabular}{|l|r|r|r|r|r|}
\hline \multicolumn{1}{|c|}{ Variabel } & N & Minimum & Maximum & Mean & $\begin{array}{c}\text { Std. } \\
\text { Deviation }\end{array}$ \\
\hline Keberhasilan UKM (Y) & 40 & 17,00 & 28,00 & 22,6500 & 2,16677 \\
\hline Laporan Keuangan (X1) & 40 & 13,00 & 25,00 & 19,9750 & 1,91469 \\
\hline Perencanaan yang Efektif (X2) & 40 & 15,00 & 24,00 & 20,6000 & 1,44648 \\
\hline Pengambilan Keputusan (X3) & 40 & 10,00 & 14,00 & 11,9750 & 1,16548 \\
\hline Penentuan HPP (X4) & 40 & 8,00 & 14,00 & 11,4000 & 1,15025 \\
\hline Penentuan Harga Jual (X5) & 40 & 16,00 & 23,00 & 19,8250 & 1,56709 \\
\hline
\end{tabular}

Sumber: Data primer, diolah (2015)

\section{Hasil Uji Kualitas Data}

Hasil uji kualitas data pada putaran pertama menunjukkan bahwa instrumen pengambilan keputusan dan penentuan HPP terdapat item pertanyaan yang tidak valid. Item pertanyaan 2, 5, dan 6 pada pengambilan keputusan menunjukkan nilai $\mathrm{r}$ hitung kurang dari 0,3120 r tabel. Hal tersebut juga ditunjukkan item pertanyaan 2 dan 5 pada penentuan HPP dengan nilai $\mathrm{r}$ hitung nilai kurang dari 0,3120 $\mathrm{r}$ tabel. Hasil uji reliabilitas instrumen pertanyaan pengambilan keputusan menunjukkan nilai $-0,116<\mathrm{r}$ tabel 0,3120 dan hasil uji reliabilitas instrumen pertanyaan penentuan HPP, menunjukkan nilai $-0,092<\mathrm{r}$ tabel 0,3120. Hasil tersebut menunjukkan bahwa seluruh instrumen pertanyaan pengambilan keputusan dan penentuan HPP tidak reliabel. 
Hasil uji kualitas data pada putaran kedua menunjukkan bahwa semua item pertanyaan dari setiap instrumen menunjukkan $r$ hitung lebih besar dari $r$ tabel. Hal ini menunjukkan bahwa seluruh item pertanyaan dari setiap instrumen adalah valid dan reliabel serta layak untuk digunakan.

\section{Analisis Regresi Linear Berganda}

1. Uji Asumsi Klasik

a. Uji Normalitas

Tabel 3

Hasil uji normalitas Kolmogorov-Smirnov

\begin{tabular}{|c|c|c|}
\hline Keterangan & Unstandardized Residual & \multirow{2}{*}{ Alpha } \\
\cline { 1 - 2 } N & 40 & \multirow{2}{*}{0,05} \\
\cline { 1 - 2 } Asymp. Signifikansi (2-tailed) & 0,388 & \\
\hline
\end{tabular}

Sumber: Data primer, diolah (2015)

Hasil uji statistik berdasarkan tabel 3 diketahui bahwa nilai signifikansi (2tailed) sebesar 0,388 lebih besar dari 0,05. Hal tersebut dapat dikatakan bahwa distribusi data adalah normal.

b. Uji Multikolinearitas

Tabel 4

Hasil Uji Multikolinearitas, Tolerance dan VIF

\begin{tabular}{|c|l|r|r|}
\hline No. & \multicolumn{1}{|c|}{ Variabel } & VIF & Tolerance \\
\hline 1 & Laporan Keuangan (X1) &, 666 & 1,502 \\
\hline $\mathbf{2}$ & Perencanaan Yang Efektif (X2) &, 589 & 1,698 \\
\hline $\mathbf{3}$ & Pengambilan Keputusan (X3) &, 777 & 1,288 \\
\hline $\mathbf{4}$ & Penentuan Hpp (X4) &, 780 & 1,282 \\
\hline $\mathbf{5}$ & Penentuan Harga Jual (X5) &, 820 & 1,219 \\
\hline
\end{tabular}

Sumber: Data primer, diolah (2015)

Berdasarkan hasil pengujian pada tabel 4, dapat dilihat bahwa perhitungan nilai VIF yang menunjukkan bahwa tidak ada satu variabel independen yang 
memiliki VIF lebih dari 10 dan nilai Tolerance variabel independen lebih dari 0,10 yang berarti tidak terdapat gejala multikolinearitas antar variabel independen.

c. Uji Heteroskedastisitas

Tabel 5

Hasil Uji Heteroskedastisitas

\begin{tabular}{|l|r|r|l|}
\hline \multicolumn{1}{|c|}{ Model } & \multicolumn{1}{c|}{ t } & \multicolumn{1}{c|}{ Sig. } & Keterangan \\
\hline (Constant) & 1,713 &, 096 & \\
\hline Laporan Keuangan (X1) & $-1,813$ &, 079 & Tidak ada heteroskedastisitas \\
\hline Perencanaan Yang Efektif (X2) &, 526 &, 602 & Tidak ada heteroskedastisitas \\
\hline Pengambilan Keputusan (X3) &, 130 &, 898 & Tidak ada heteroskedastisitas \\
\hline Penentuan HPP (X4) &,- 134 &, 894 & Tidak ada heteroskedastisitas \\
\hline Penentuan Harga Jual (X5) & $-1,277$ &, 210 & Tidak ada heteroskedastisitas \\
\hline a. Dependent Variable: abs_res & &
\end{tabular}

Sumber: Data primer, diolah (2015)

Berdasarkan hasil uji dalam tabel 5 menunjukkan bahwa semua variabel memiliki nilai signifikan lebih besar dari 0,05 . Hasil tersebut dapat dikatakan bahwa tidak ada heteroskedastisitas.

\section{Hasil Pengujian Hipotesis}

Tabel 6

Hasil Analisis Regresi Linear Berganda

\begin{tabular}{|c|l|c|c|l|}
\hline No & \multicolumn{1}{|c|}{ Variabel } & Signifikansi & Alpha & \multicolumn{1}{|c|}{ Keputusan } \\
\hline 1 & Laporan Keuangan & 0,115 & 0,05 & $\mathrm{H}_{1}$ ditolak \\
\hline 2 & Perencanaan yang Efektif & 0,004 & 0,05 & $\mathrm{H}_{2}$ diterima \\
\hline 3 & Pengambilan Keputusan & 0,000 & 0,05 & $\mathrm{H}_{3}$ diterima \\
\hline 4 & Penentuan HPP & 0,002 & 0,05 & $\mathrm{H}_{4}$ diterima \\
\hline 5 & Penentuan Harga Jual & 0,001 & 0,05 & $\mathrm{H}_{5}$ diterima \\
\hline
\end{tabular}

Variabel Dependen $=$ Keberhasilan UKM

F Statistik $\quad=9,461$

Signifikansi $\quad=0,000^{\mathrm{a}}$

Adjusted $R^{2} \quad=0,520$

Sumber: Data primer, diolah (2015) 


\section{a. Uji Koefisien Determinasi}

Berdasarkan hasil uji pada tabel 6 , nilai adjusted $R$-square menunjukkan angka sebesar 0,520 yang berarti pengaruh variabel independen atau koefisien determinasi pada penelitian ini adalah sebesar 52\%. Analisis regresi secara keseluruhan menunjukkan $\mathrm{R}$ sebesar 0,763 yang berarti bahwa korelasi/hubungan antara laporan keuangan, perencanaan yang efektif, pengambilan keputusan, penentuan HPP, dan penentuan harga jual terhadap keberhasilan UKM mempunyai hubungan yang kuat sebesar 76,3\%. Dikatakan kuat karena angka tersebut di atas 0,5 atau $50 \%$.

b. Uji Signifikansi Simultan (F)

Berdasarkan hasil uji pada tabel 4.29 diatas, dapat dikatakan bahwa F hitung 9,461 > F tabel 2,45, dengan nilai sig. < 0,05. Berarti variabel laporan keuangan, perencanaan yang efektif, pengambilan keputusan, penentuan HPP, dan penentuan harga jual secara bersama-sama berpengaruh signifikan terhadap keberhasilan UKM.

c. Uji Signifikansi Parsial (t)

Variabel laporan keuangan berdasarkan hasil uji pada tabel 6 menunjukkan tingkat signifikansi 0,115 lebih besar dari 0,05 yang berarti variabel laporan keuangan dapat dikatakan tidak berpengaruh terhadap keberhasilan UKM. Hal ini berarti menjelaskan bahwa hipotesis pertama ditolak. Sementara itu, variabel perencanaan yang efektif menunjukkan tingkat signifikansi 0,004 lebih kecil dari 0,05 yang berarti variabel perencanaan yang efektif berpengaruh keberhasilan UKM. Hal ini menunjukkan bahwa hipotesis kedua diterima.

Variabel pengambilan keputusan berdasarkan hasil uji menunjukkan tingkat signifikansi 0,000 lebih kecil dari 0,05 yang berarti variabel pengambilan keputusan berpengaruh terhadap keberhasilan UKM. Hal ini menunjukkan bahwa hipotesis ketiga diterima. Variabel penentuan HPP berdasarkan menunjukkan tingkat signifikansi 0,002 lebih kecil dari 0,05 yang berarti variabel penentuan HPP berpengaruh terhadap keberhasilan UKM. Hal ini menunjukkan bahwa hipotesis keempat diterima.

Variabel penentuan harga jual berdasarkan hasil uji pada tabel 4.29 diatas menunjukkan tingkat signifikansi 0,001 lebih kecil dari 0,05 yang berarti variabel 
penentuan harga jual berpengaruh terhadap keberhasilan UKM. Hal ini menunjukkan bahwa hipotesis kelima diterima.

\section{Pembahasan}

Hasil penelitian menunjukkan bahwa hipotesis pertama (H1) yaitu laporan keuangan tidak berpengaruh terhadap keberhasilan UKM. Hasil tersebut bertolak belakang dengan hasil penelitian yang dilakukan oleh Kiryanto dan Sutapa (2001) dalam Prasetya (2006) dikutip dalam Permana (2014) yang menyatakan bahwa informasi akuntansi keuangan berpengaruh terhadap keberhasilan perusahaan kecil. Berdasarkan pengamatan di lapangan ketika peneliti mengambil data dari responden dengan kuesioner, rata-rata para pelaku usaha tidak terlalu memperhatikan akan laporan keuangan dari usaha mereka.

Hasil analisis menunjukkan bahwa hipotesis kedua $(\mathrm{H} 2)$ yaitu perencanaan yang efektif berpengaruh terhadap keberhasilan UKM. Menurut Supriyanto (2009), perencanaan usaha/bisnis sangat berguna untuk menilai usaha/bisnis yang akan kita tekuni layak, profitabel dan berjangka panjang/berprospek. Hasil ini bertolak belakang dengan hasil penelitian yang dilakukan oleh Permana (2014) yang menyatakan bahwa perencanaan yang efektif tidak berpengaruh terhadap keberhasilan UKM.

Hasil analisis menunjukkan bahwa hipotesis ketiga (H3) yaitu pengambilan keputusan berpengaruh terhadap keberhasilan UKM. Hasil ini juga bertolak belakang dengan hasil penelitian yang dilakukan oleh Permana (2014), yang menyatakan bahwa pengambilan keputusan tidak berpengaruh terhadap keberhasilan UKM. Berdasarkan pengamatan saat pengambilan data dengan menyebar kuesioner, para pelaku usaha dalam hal ini adalah pengrajin kulit juga memperhatikan setiap keputusan yang akan mereka lakukan dalam usaha.

Hasil analisis menunjukkan bahwa hipotesis keempat (H4) yaitu penentuan HPP berpengaruh terhadap keberhasilan UKM. Hasil ini sesuai dengan pernyataan Rachmayanti (2011) yang menyatakan bahwa informasi harga pokok produksi dapat dijadikan titik tolak dalam menentukan harga jual yang tepat kepada konsumen dalam arti yang menguntungkan perusahaan dan menjamin kelangsungan hidup perusahaan. Berdasarkan pengamatan saat pengambilan data, para pengrajin kulit 
juga sudah memperhitungkan harga pokok produksi dari usaha yang mereka lakukan meskipun dengan metoda yang sederhana.

Hasil analisis menunjukkan bahwa hipotesis kelima (H5) yaitu penentuan harga jual berpengaruh terhadap keberhasilan UKM. Hasil ini sesuai dengan penelitian yang telah dilakukan oleh Permana (2014) yang menyatakan bahwa penentuan harga jual berpengaruh terhadap keberhasilan UKM.

\section{SIMPULAN, KETERBATASAN, DAN SARAN}

Berdasarkan hasil analisis data tentang pengaruh informasi akuntansi terhadap keberhasilan UKM diperoleh simpulan sebagai berikut:

1. Laporan keuangan tidak berpengaruh terhadap keberhasilan UKM.

2. Perencanaan yang efektif berpengaruh terhadap keberhasilan UKM.

3. Pengambilan keputusan berpengaruh terhadap keberhasilan UKM.

4. Penentuan HPP berpengaruh terhadap keberhasilan UKM.

5. Penentuan harga jual berpengaruh terhadap keberhasilan UKM.

Penelitian ini memiliki keterbatasan yang mungkin pada penelitian selanjutnya dapat dijadikan perbaikan. Keterbatasan dalam penelitian ini adalah kurangnya pengetahuan dari para pelaku usaha akan informasi akuntansi dikarenakan tingkat pendidikan yang sebagian besar hanya sampai tingkat sekolah dasar. Pelaku usaha juga belum memahami akan pentingnya informasi akuntansi untuk keberlangsungan usaha mereka. Selain itu, jumlah responden yang juga kurang banyak karena keterbatasan waktu.

Berdasarkan keterbatasan dalam penelitian ini, peneliti menyarankan beberapa hal, antara lain adalah:

1. Bagi Penelitian Selanjutnya

a. Indikator penelitian dapat diganti/menambahkan dengan proksi yang lain untuk penelitian selanjutnya, misalnya menambahkan pertanyaan penerapan analisis SWOT dalam perencanaan yang efektif, menambahkan pertanyaan metoda harga jual yang digunakan dalam penentuan harga jual.

b. Kuesioner untuk penelitian selanjutnya agar spesifik lagi, karena kuesioner dalam penelitian ini masih terlalu luas. 
c. Penelitian selanjutnya sebaiknya mempertimbangkan perluasan sampel penelitian, baik dari segi kriteria sampel maupun waktu pengamatan agar lebih mudah dalam analisis data.

2. Bagi Pemerintah

a. Perlunya pendampingan yang lebih maksimal lagi bagi para pelaku usaha. Seperti, menambah kuantitas pelatihan dan memperhatikan kualitas dari pelatihan seperti menekankan masalah pentingnya membuat laporan keuangan. Hal tersebut dikarenakan para pelaku usaha kurang begitu memperhatikan pentingnya laporan keuangan.

b. Lebih diperkuat kembali pemahaman bagi para pelaku usaha akan informasi akuntansi untuk keberhasilan usaha serta pemahaman akan pentingnya informasi akuntansi.

\section{DAFTAR PUSTAKA}

Academia.edu. 2015. Analisis Pengambilan Keputusan [Online]. Didapatkan: https://www.academia.edu (diakses 9 April 2015).

Academia.edu. 2015. Skala Likert [Online]. Didapatkan: http://www.academia.edu/7233329/Skala_Likert (diakses 16 April 2015).

Bantulmedia.com. 2013. Sentra Pembuatan Wayang Kulit Pucung Wukirsari Imogiri Bantul [Online]. Didaptkan: http://bantulmedia.com/2013/05/sentrapembuatan-wayang-kulit-pucung-wukirsari-imogiri-bantul.html (diakses 16 Agustus 2015).

BPS.go.id. 2015. Tabel Statistik[Online]. Didaptkan: http://bps.go.id/linkTabelStatis/view/id/1770 (diakses 14 April 2015).

Ghozali, Imam. 2011. Aplikasi Analisis Multivariate dengan Program IBM SPSS 19 (edisi 1). Semarang: Badan Penerbit Universitas Diponegoro.

Hanum, Zulia. 2013. "Pengaruh Persepsi Pengusaha Kecil atas Informasi Akuntansi Keuangan terhadap Keberhasilan Perusahaan". Jurnal Riset Akuntansi dan Bisnis. Volume 13, Nomor 2. Hal. 219-250. Didapatkan: http://jurnal.umsu.ac.id (diakses 25 Oktober 2014).

Harahap, Yenni Ramadhani 2014. "Kemampuan Menyusun Laporan Keuangan yang Dimiliki Pelaku UKM dan Pengaruhnya terhadap Kinerja UKM". Jurnal 
Riset Akuntansi dan Bisnis. Volume 14, Nomor 1. Hal. 66-76. Didapatkan: http://jurnal.umsu.ac.id (diakses 25 Oktober 2014).

Hastono, Sutanto Priyo. 2006. Analisis Data. Jakarta: Universitas Indonesia.

Jogjatrip.com. 2015. Sentra Kerajinan Kulit Desa Manding[Online]. Didapatkan: http://jogjatrip.com/id (diakses 24 Maret 2015).

Kuncoro, Mudrajad. 2011. Metode Kuantitatif: Teori dan Aplikasi untuk Bisnis dan Ekonomi. Edisi Keempat. Yogyakarta: UPP STIM YKPN.

Martusa, Riki dan Agnes Fransisca Adie. 2011. "Peran Activity-Based Costing System dalam Perhitungan Harga Pokok Produksi Kain yang Sebenarnya untuk Penetapan Harga Jual". Akurat Jurnal Imliah Akuntansi. Nomor 4. Tahun ke-2 Januari-April 2011. Didapatkan: http://repository.maranatha.edu (diakses 23 April 2015)

Mas'ud, Machfoedz. 1995. Akuntansi Manajemen. Yogyakarta: STIE Widya Wiwaha.

Mujib, Moh. Fatkhul. 2010. Analisis Faktor-Faktor yang Berpengaruh Langsung dan Tidak Langsung terhadap Kinerja Usaha Kecil \& Menengah (UKM)[Online]. Skripsi. Semarang: Fakultas Ekonomi Universitas Diponegoro. Didapatkan: http://eprints.undip.ac.id (diakses 29 April 2015)

Mulyadi. 2007. Akuntansi Biaya. Yogyakarta: BPFE-UGM.

Nasional.sindonews.com. 2013. Tantangan \& Peluang AEC [Online]. Didapatkan: http://nasional.sindonews.com/read/738037/18/tantangan-peluang-aec1365982809 (diakses 9 April 2015).

Permana, Adhi. 2014. Pengaruh Persepsi Informasi Akuntansi dan Motivasi Karyawan terhadap Keberhasilan Usaha Kecil dan Menengah. Yogyakarta: Skripsi. FE UAD.

Pinasti, Margani. 2007. Pengaruh Penyelenggaraan dan Penggunaan Informasi Akuntansi terhadap Persepsi Pengusaha Kecil atas Informasi Akuntansi: Suatu Riset Eksperimen[Online]. Didapatkan: http://multiparadigma.lecture.ub.ac.id (diakses 25 Maret 2015).

Rachmayanti, Dewi Kasita. 2011. Analisis Perhitungan Harga Pokok Produksi Sepatu dengan Metode Full Costing[Online]. Skripsi. Bogor: Fakultas Ekonomi dan Manajemen IPB. Didapatkan: http://repository.ipb.ac.id (diakses 27 Februari 2015).

Rahmana, Arif. 208. Usaha Kecil dan Menengah (UKM), Informasi Terdepan tentang Usaha Kecil Menengah[Online]. Didapatkan: 
http://infoukm.wordpress.com (diakses 4 April 2015)

Rozi, Ahmad. 2010. Penentuan Harga Pokok Produksi Lele pada Petani Lele di Desa Tuntang[Online]. Skripsi. Semarang: Fakultas Ekonomi Universitas Diponegoro. Didapatkan: http://eprints.undip.ac.id (diakses 11 Maret 2015)

Sekaran, Uma. 2006. Metodologi Penelitian untuk Bisnis. Edisi Empat. Jakarta: Salemba Empat.

Setneg.go.id. 2014. Peluang dan Tantangan Indonesia pada ASEAN Economic Community 2015[Online]. Didapatkan: http://www.setneg.go.id (diakses 28 Oktober 2014)

Sindonews.com. 2013. Tantangan \& Peluang AEC [Online]. Didapatkan: http://nasional.sindonews.com/read/738037/18/tantangan-peluang-aec1365982809 (diakses 28 Oktober 2014).

Suandy, Erly. 2001. Perencanaan Pajak. Edisi Revisi. Jakarta: Salemba Empat.

Sugiri, Slamet., dan Sulastiningsih. 2004. Akuntansi Manajemen. Yogyakarta: UPPAMP YKPN.

Sugiyono. 2009. Metode Penelitian Bisnis. Bandung: Alfabeta.

Supriyanto. 2009. "Business Plan sebagai Langkah Awal Memulai Usaha". Jurnal Ekonomi \& Pendidikan. Volume 6, Nomor 1. Hal.73-83. Didapatkan: http://journal.uny.ac.id (diakses 4 April 2015).

Wahyudi, Muhamad 2009. Analisis Faktor-faktor yang Mempengaruhi Penggunaan Informasi Akuntansi pada Usaha Kecil dan Menengah (UKM) di Yogyakarta[Online]. Tesis. Semarang: Universitas Diponegoro. Didapatkan: http://eprints.undip.ac.id (diakses 23 Februari 2015).

Wibowo, Alex., dan Elisabeth Penti Kurniawati. "Pengaruh Penggunaan nformasi Akuntansi terhadap Keberhasilan UKM". Economics \& Business Research Festifal. Tahun ke-3 November 2014. Didapatkan: http://repository.uksw.edu (diakses 4 April 2015).

Widiyastuti, Sri. 2007. Analisis Perhitungan Harga Pokok Produksi Tas Wanita[Online]. Skripsi. Bogor: Fakultas Ekonomi dan Manajemen Institut Pertanian Bogor. Didapatkan: http://repository.ipb.ac.id (diakses 12 Mei 2015)

Wirjoyo, Endang Raino., dan D. Agus Budi Raharjo. "Survei Pemahaman dan Pemanfaatan Informasi Akuntansi dalam Usaha Kecil Menengah di Daerah Istimewa Yogyakarta”. Jurnal Akuntansi \& Bisnis. Volume 7, Nomor 2. Hal.205-2016. Didapatkan: http://ojs.unud.ac.id (diakses 23 Februari 2015). 